\title{
血球及ビ細菌チ以テ丕疫七ル場合ノ細菌 凝集素
}

京都帝國大學醫學部微生物學敉室（主任 木村㸚授）

丸野 秀 雄

\section{【内容 抄 錄】}

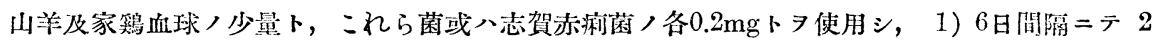

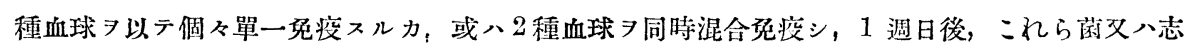

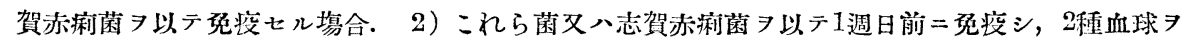

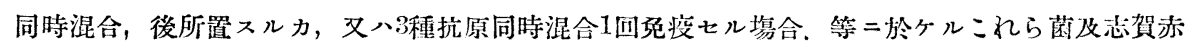
㾥菌, 凝集素産生狀態》檢索七り.

目

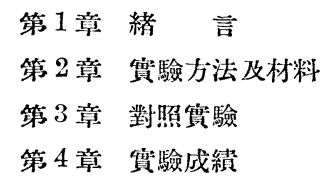

第 1 節 血球 7 以免度シ，後これら菌 以テ免狻セル塲合

第 2 節，血球 7 以急疫シ，後志賀赤捒菌 ヨ以テ烣疫セル塲合

第 3 節 これら菌 7 以 1 回免疫シ，6日間 隔 テテ, 其 $/$ 前, 或八後 $=2$ 種血
次

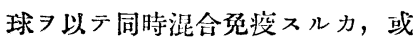
八 3 種抗原同時混合 1 国免落七ル 笏合

第 4 節 志賀赤莉菌 7 以 1 回免疫シ，6日 間隔ニテ, 其ノ前, 或八後二, 2 種血球 7 以同時混合免济スルカ 或八 3 種抗原同時混合 1 回免度七 儿管合

第 5 章 結 論

參考文陮

\section{第 I 章 緒}

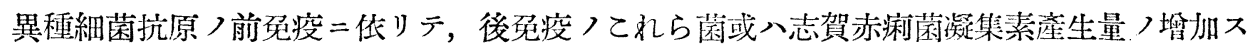

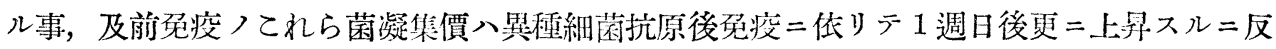

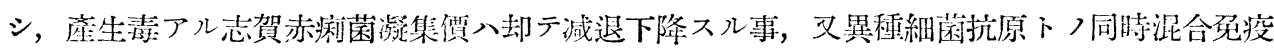

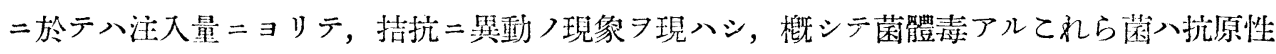

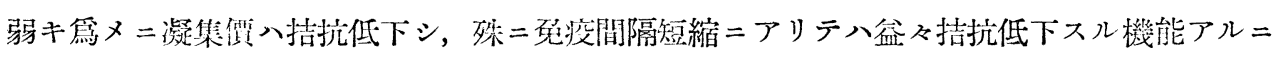

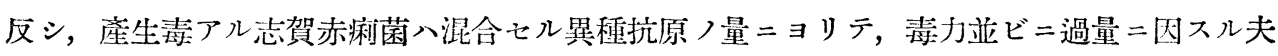

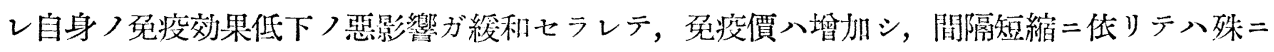
其機能著明ナル事ヨ報告セリ．又微量ナル山羊及牛ノ血清トちふす菌卜ノ混合免疫ニ於テへ

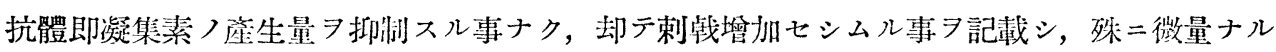

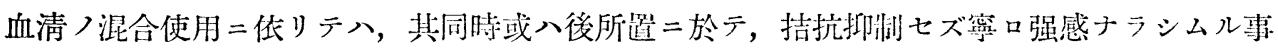




丸 野 秀 雄 述

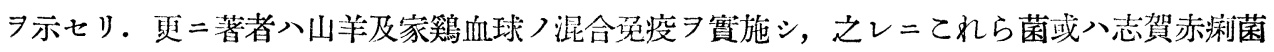

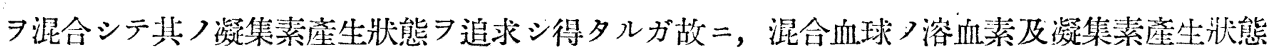

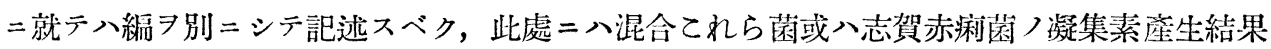
ノミヨ記酨スベシ.

\section{第 2 章 實驗方法及材料}

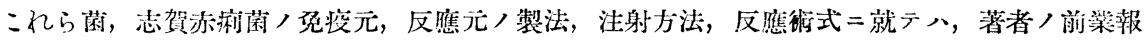

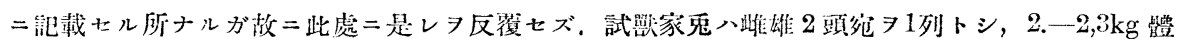

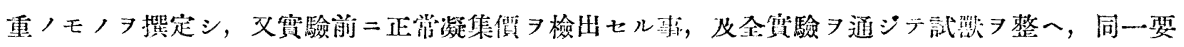

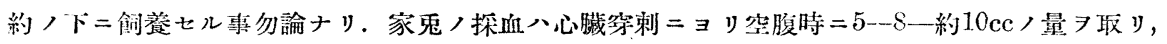

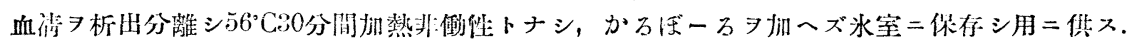

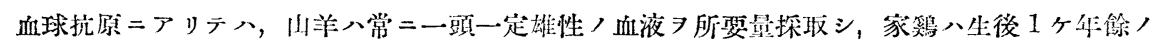

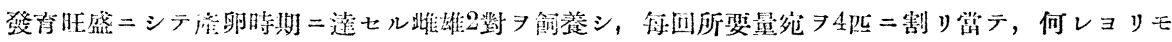

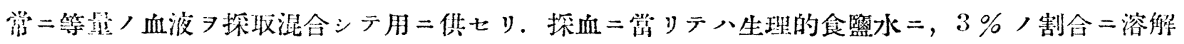

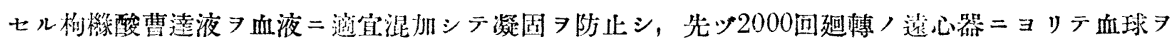

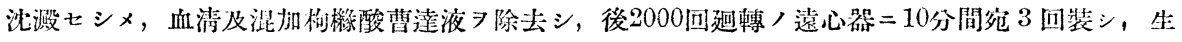

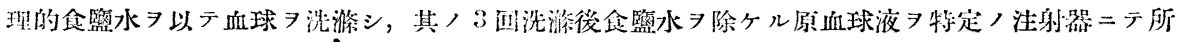

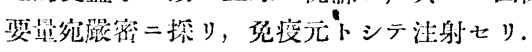

\section{第 3 章 對 照 實 驗}

$$
\text { 第 } 1 \text { 表 }
$$

(1)

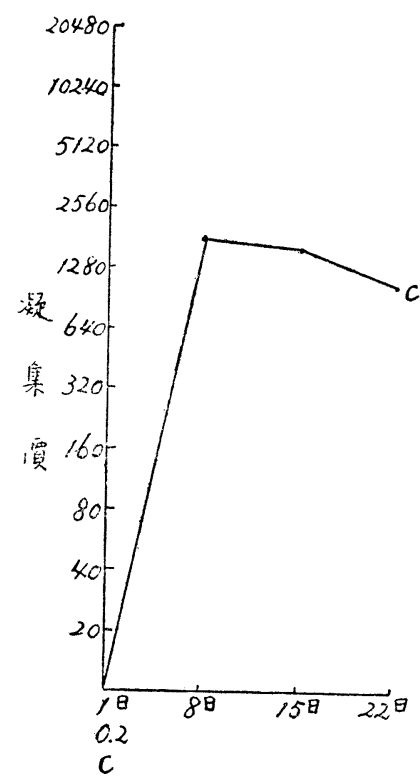

(2)

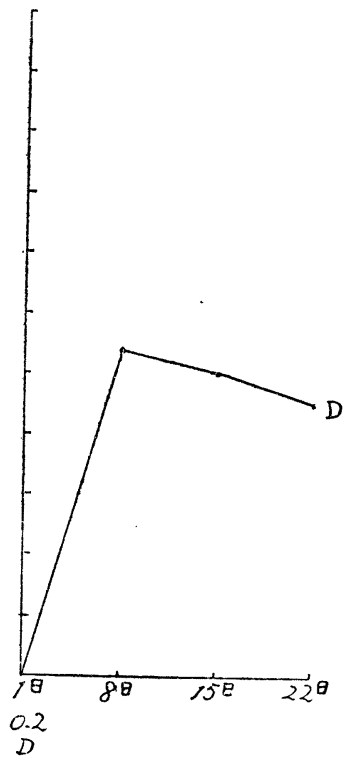

偏考；(1），賽線ハこれら 菌凝集價. (2) 八志賀赫㢉 菌凝集價 示ス。 C ハニれ

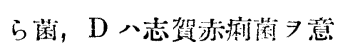
味又.

免没元，免没量及及應检查日次

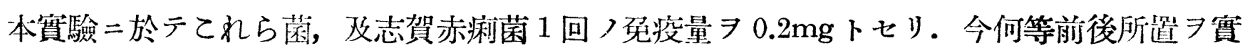


施セザル單一免疫ノ對照價 フ示セバ第 1 表ニ於ケル曲線ノ如シ．即チてれら菌八免疫後 1 週 日二八1920倍，第 2 週白 1440 倍，第 3 週日 1120 倍 示シ，志賀赤莉菌八第 1 週日 =八400倍, 第2週日ハ 320 倍，第 3 週日ニハ 240 倍ヨ示シ，此使用菌株及菌量ニテハてれら菌ノ凝集價 八

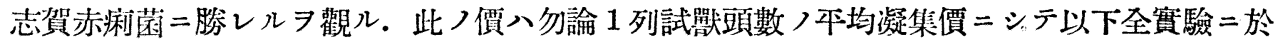
テ然リトス. 因二前編二記述セル如ク菌體混合ノ前業報ニ於ケル菌株ト八晎ナルモノラ以テ セリ.

\section{第 4 章 宽 驗 成 績}

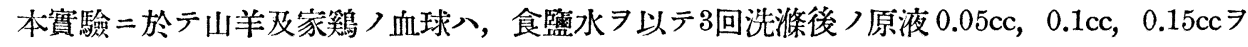
特定ノ注射器二取リ, 更二生理的食邷水 1 乃至 $2 \mathrm{cc}$ 吸取リ混加シ, 能ク浮游セシメタル後, 家质ノ耳青脈 $コ$ リ注射七リ。

\section{第 I 節 血球ヨ以テ免没シ後これら菌ヨ以テ免疫セル臯合}

第 2 表

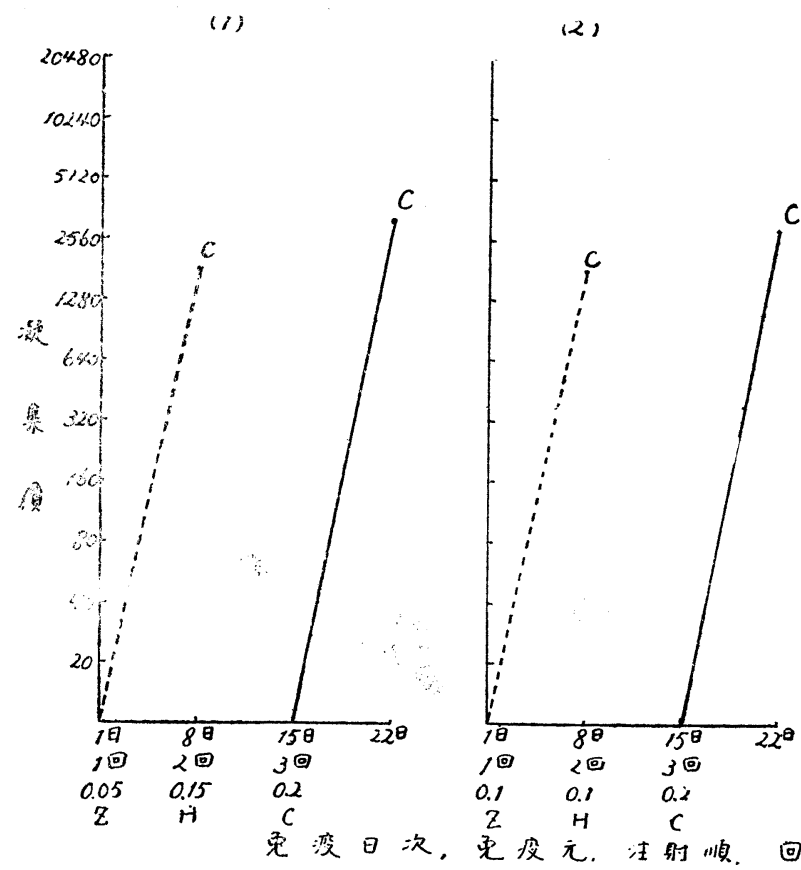

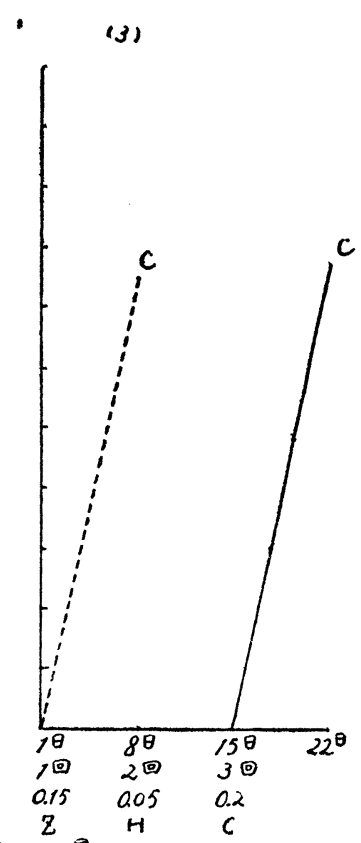

数. 量

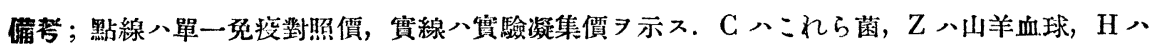
家䉆血球 7 意味ス.

先ヅ 3 組 $=$ 分チ, 6 日間隔 于 $(1)=$ 八山羊血球 $0.05 \mathrm{cc}$, 家鹙血球 $0.15 \mathrm{cc},(2)=$ 八山羊血球 $0.1 \mathrm{cc}$, 家鴙血球 $0.1 \mathrm{cc},(3)=八$ 


\begin{tabular}{ccccc} 
丸 & 野 秀 雄 述 & $(55)$ \\
\hdashline
\end{tabular}

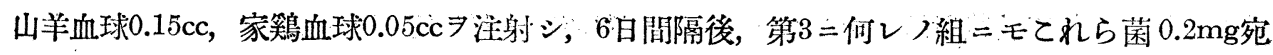
习後乔疫七リ. 其成績八第 2 表二示セル所ナリ。

第2表つ結果入 $(1)$ =於テハ 3200 倍，(2)ニアリテハ2880倍，(3)=アリテハ2240倍〉㠜集價

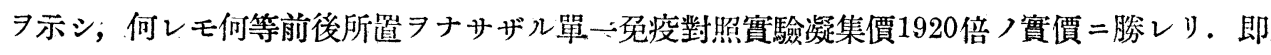
千異種細菌抗原前免疫二於ヶル如ク, 小量〉異種抗原山羊及家箕血球〉前免疫ニョリテ, 乙

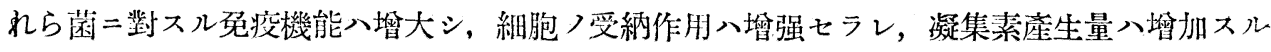
モノト謂ハザル可カラズ.

\section{第 2 節 血球 セル場合}

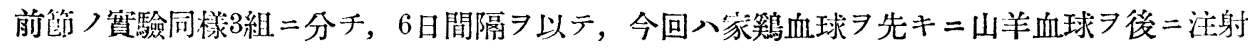
七リ. 即 $千(1)=$ 家鴙血球 $0.05 \mathrm{cc}$, 山羊血球 $0.15 \mathrm{cc},(2)=八$ 家䉣血球 $0.1 \mathrm{cc}$, 山羊血球 $0.1 \mathrm{cc}$,

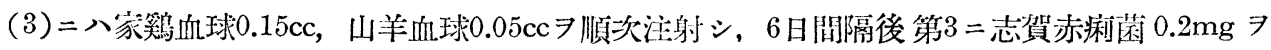
何レノ組 ニモ耳静脈ヨリ注入七リ，其ノ結果八第 3 表ニ於ヶルガ如シ.

第 3 表

(I) (2)
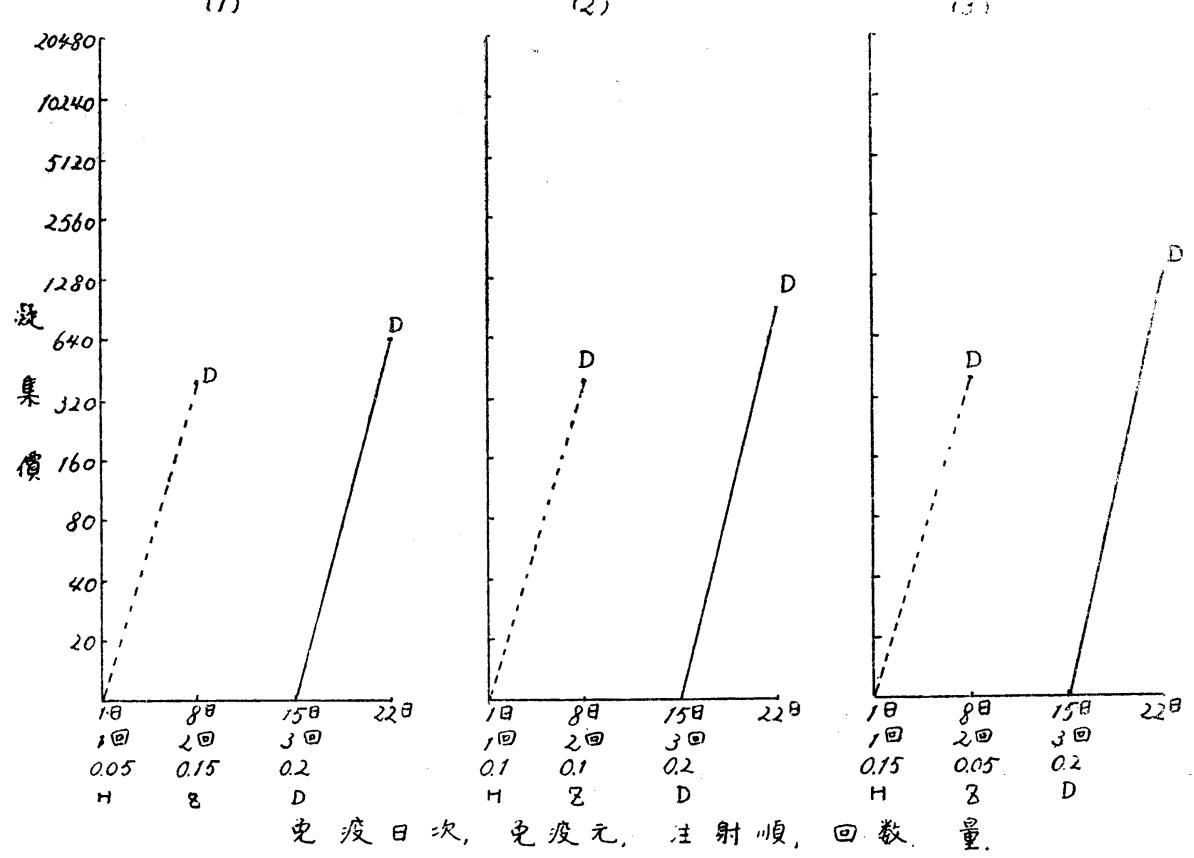

免渡日次, 免没元, 注射順, 回数、量。

備君; D八志賀赤㾥菌

第3表ノ結果八 $(1)=$ 於テハ 640 倍，(2)ニアリテハ 960 倍，(3)ニアリテハ1280倍ノ凝集價 


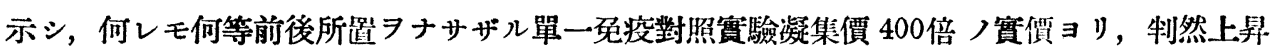
率增加スル事ヨ識ル。茲二於テカ產生毒アル志賀赤痢菌二於テモ, 菌體毒アルてれら菌二於 ケルガ如ク，異種抗原ナル細菌體ノミナラズ，又小量ノ山羊及家䉆血球ノ前免疫 $=ョ リ テ ，$ 志賀赤㾥菌 =對スル細胞ノ受納作用八增强七ラレ, 凝集素產生量八增加スル事ヨ明示セリ。 因二此ノ最小致死量 得タル八，異種細菌前免疫卜同樣二，志賀赤痢菌二對スル組織細胞ノ抵抗ヨ增大七シムル事 證スルモノナリ。

\section{第 3 節 これら菌州以回免疫シ，6日間隔ニテ其ノ前或八後 =2種血球尹以テ同時混合免疫スルカ, 或ハ3種抗原同 時混合|回免洨セル鳆合}

第 4 表

2)

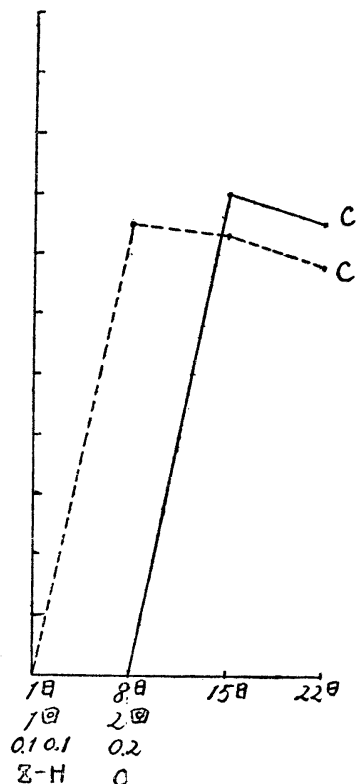

(3)

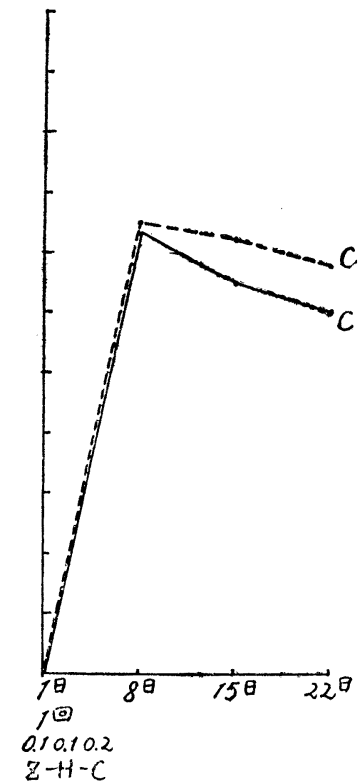

免湾日次, 免没元, 注射顺, 回数, 量。

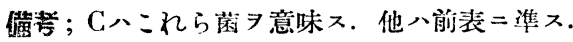

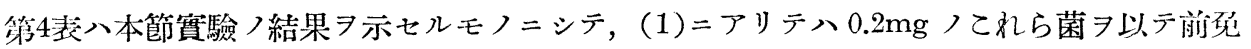

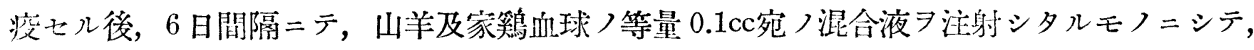

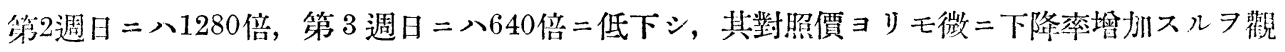
ルハ, 多少抑壓驅逐七ラルルノ現像アリトスベク, ちふす菌ト微量つ山羊及牛血清トノ混合 
丸野秀雄述

乔疫ニ於ケル塲合二反スル結果ラ觀ルハ，其ノ如何ナル㸃二基因スルモノナルや，著者ノ一 概二斷定シ得ザル所ナレドモ，恐ラク其ノ抗原性及抗原成分二關係スル所ナル可ク，類脂體 ナルヤ，含水炭素丈八血球蛋白二因由スルヤ八不明ノ點トス．鬼モアレ全然獨立的二經過七 ズ抑望驅逐セラルル状態ト云八ザル可カラズ．（2）八實驗ニアリテハ，前者卜反對＝各等量 $0.1 \mathrm{cc}$ 宛 山羊及芜䉣血球ノ混合液

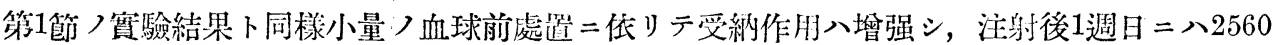
倍二達シ，次週二到レバ 1920 倍二漸次减退低下ス．然レドモ對紧例二比シテ其）高位ヨ持

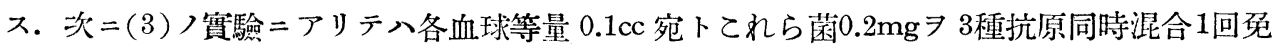
疫七ルモノニシテ，其ノ凝集價入 1760 倍 示シ，是等血球ノ混合量

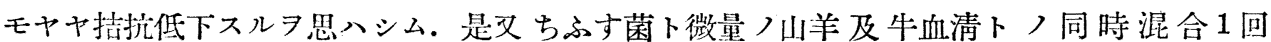

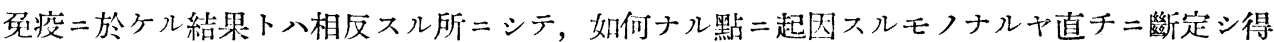
ザル所ナレドモ，恐ラク各抗原量＝關係シ，又其抗原性つ强弱及抗原成分等二因由スルモ， ナル可ク，拮抗低下スル脶態ト謂ハザル可カラズ，而シテ第2週日 960 倍第3週日ハ 640 倍 $=$ 下 降シ，其下降率八對照例二勝リ，（1）八實驗ニ於ヶルガ如ク低下スルハ又抑壓驅逐つ叔態二 存スルト謂フ可シ.

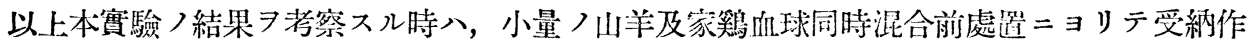
用八增强シ後㣻疫ノてれら菌凝集價八上昇ス，然レドモ同時混合星疫ニアリテハヤヤ怙抗低 下シ其後ノ下降率モ全然獨立的二經過セズシテ驅逐セラルルモノノ如シ. 又單一 1 回前免疫

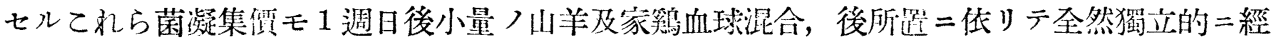
過セズ，驅逐七ラルル状態ヨ示シ下降率八對照價二勝ル。斯ク血球ノ後或八同時所造つ後抗 體减退度ノ增加スル倾向アル八著者〉直チ二此處二斷定シ得ザル所ナリ。

\section{第 4 節 志賀赤㰾菌习以テ1圆免疫シ，6日間隔ニテ其ノ前或ハ後

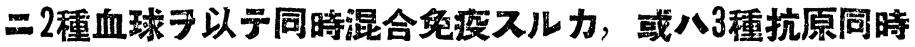 混合｜回免疫也ル圔合}

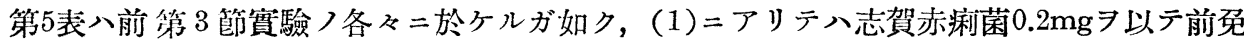
疫シ, 6 日間隔後山羊血球 $0.15 \mathrm{cc}$, 家鶏血球 $0.05 \mathrm{cc}$ >混合液 其凝集價八第 2 週日 240 倍，第 3 週日 160 倍ノ消長經過ヨ示シ，前節乙れら菌ニ於ヶルト同㥞二 全然獨立ノ經過

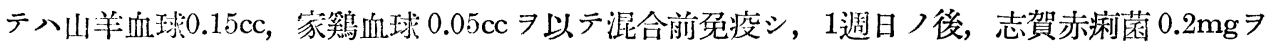
注射シタル塲合ニシテ，第2筑ノ實驗結果，或八第3笁實驗 $(2)$ 結果卜同樣，志賀赤痢菌凝

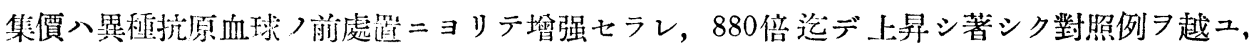


第 5 表

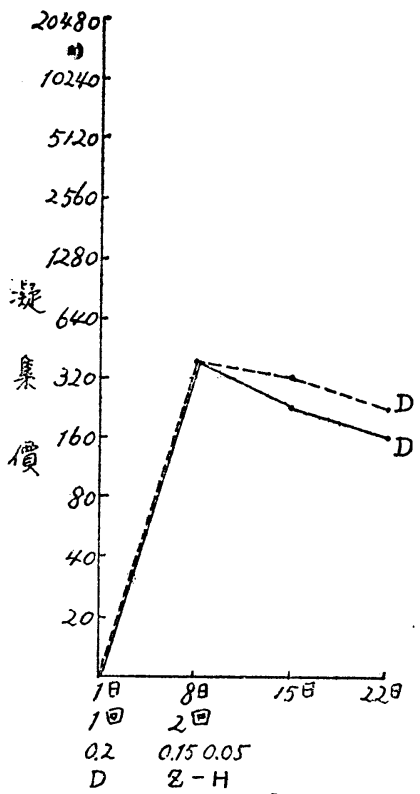

(2)

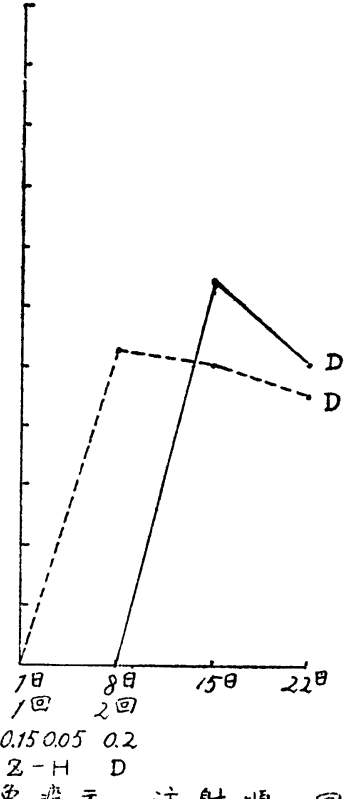

(3)

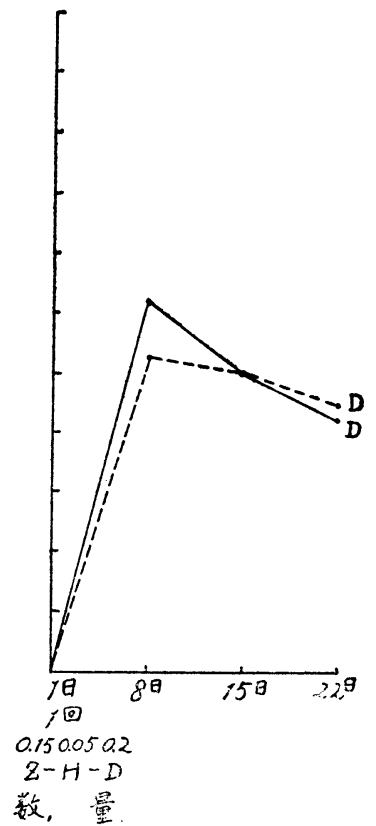

備责; D八志賀赤莉菌 7 意味

然レドモ次週ニ八又頗ル减退度ヨ增シ對照例卜同高二到リ 320 倍 ヨ示シ，てれら菌つ如ク對 照例 =比シ高位 抗體卜ノ間二何等カ因果關係つ存スル所ナル可ク，此處ニ之レヨ論斷シ得ザル點ナリト雖モ

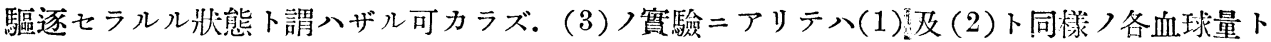

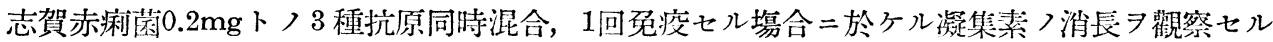
モノニシテ，本例二於テハ前第3節(3)ノこれら菌凝集價二反シ，對照價ヨリ著シク上景スル

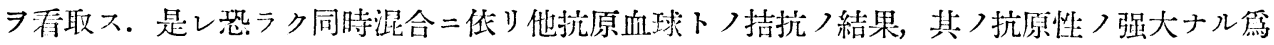
メニ來タレル現象ナル可シ。而シテ (2) ト同樣次週二八义著シク减退シテ對照偪卜同高二居 リ，第 3 週日二八更二對照賈ヨリモ低下スル傾向 アル點ニシテ，(1)，(2)，(3) ノ各例二此ノ現像フ䚋ルハ看過シ得ザルモノナリ．恐ラク何 等カ各抗體間二相影響スル因子ノ存スルモノニアラザルナキャフ疑フモノナリト踓モ, 其如 何ナル點二因由スルヤ八此處二明言シ得ザル所ナリ。

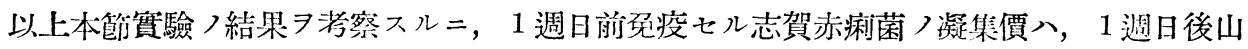
羊及家䉆血球ノ小量混合液 
シこれら菌ニ於ケルト同様全然獨立的二經過七ザルノ態度フ取ル。而シテ反對二血球混合

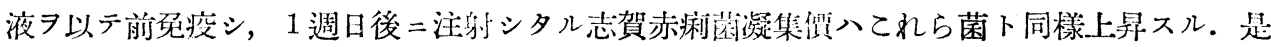

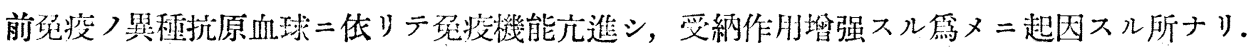
然レドモ，其ノ减退下降ノ度ハ又著シクシテ，全然獨立經過スルノ狀態习呈セザル傾向 ヨ示

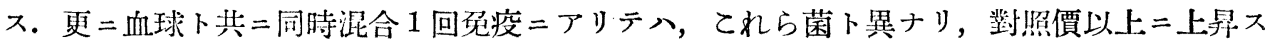
ル. 是叙上ノ如ク恐ラク血球抗原卜ノ拮抗ノ結果，其〉抗原性つ强大ナル営メ二來夕ル現象 ナル可ク，斯クノ如キ八異種細菌抗原卜志賀赤痢菌卜ノ混合否疫二於テモ發現スル所ナリ。 而シテ其ノ下降率ニアリテハ, 何等前後所路セザル對照價ヨリモ著シク，逐二對照價以下二 下降スルヨ觀レバ，他抗體卜ノ共存二不利ナル因子ノ存在スル事ヨ想到スルモノニシテ驅逐 セラルルモノト謂フ可シ，然レドモ如何ナル因子二蹄ス可キヤ八著者ノ此處二斷ジ得ザル點 トス.

\section{第 5 章 結 論}

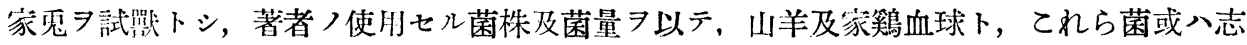

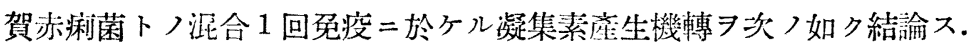

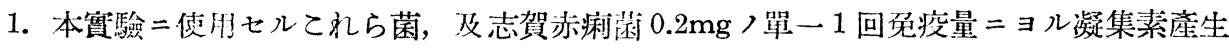
量ハこれら菌䐁儿。

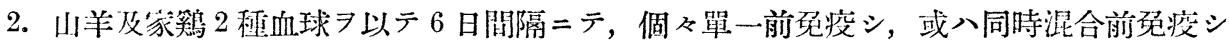

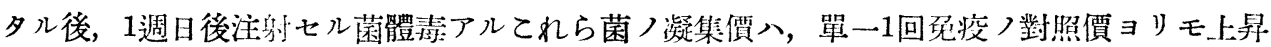
ㅈ.

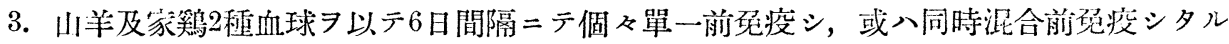

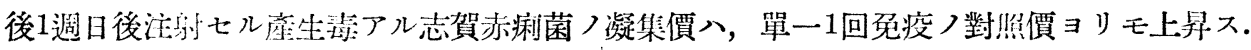

4. 乙れら菌ノ小量 $7 以 テ 1$ 回前争疫シ，6 日閒隔後山羊及家䉆 2 種血球 7 混合注射スル時

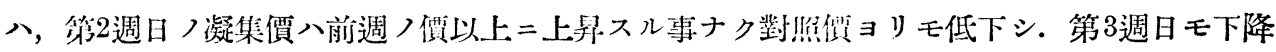

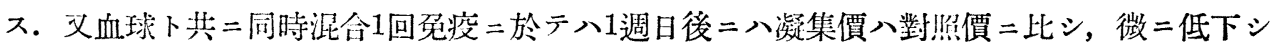
第2週日，第3週日共 = 對!照價 $コ$ モ下降率多シ。

5. 志賀赤痢菌ノ最小致死量 $7 以 テ$ 前免疫シ, 6 日間隔後，山羊及家䉆 2 種血球 7 䟗合注射 スル時八，第2週日ノ㠜集價八前週ノ價以上二上昇

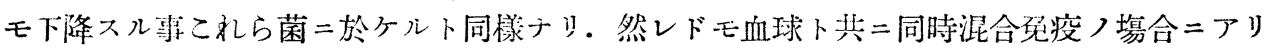

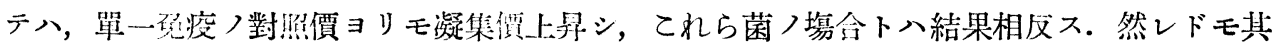

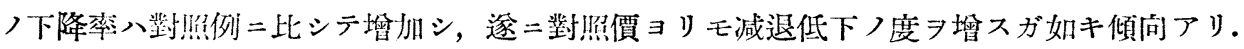

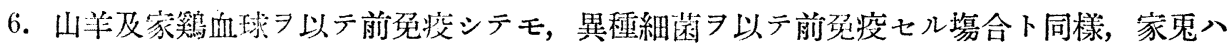


志賀赤㾰菌最小致死量 $=$ 堪へ得ルノ抵抗 $ᄏ$ 得ルト共二，一面凝集素ノ產生量八增加ス.

附記；以上本實驗八昭和7年10月9日ョリ，同年11月24日二亘りテ賽施終了七ル事 7 附訅ス。

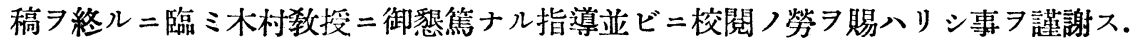

\section{勢荅 文献}

1) Michaelis, Handb. der Biochem. von Oppenheimer. Bd. 2, 1910.2 2) 丸野秀雄, 日

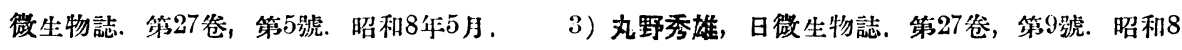
年8月. 4) E. Benjamin u. O. Witzinger, Z. f. Kinderh. Orig. Bd. 2, 1911. Bd. 3, 1912. 5) Weichardt u. Schrader, Münch, med, Wschr. $1919 . \quad 6)$ Weichardt, Urspezifische Immunität 1926. 7) Much, Dtsch. med.Wschr. $1920 . \quad$ 8) Castellani, Zbt. f. Bakt. 1. Orig. Bd. 77, 1915.9 9) K. Landsteiner, Biochem. Zeitschr. Bd. 119, 1921. 10) K. Landstiner u. Simms, Te J. Exp. Med. Vol. 38, $1923 . \quad 11$ ) R. Kraus, Z. f. Immun, Bd. 41, $1924 . \quad 12$ ) N. Takenomata, Z. f. Immun. Bd. 41, 1924. 13) Kraus, Penna u. Cuenca, W. klir. Wschr. 1917 . 14) K. Imai, Z f. Immun. Bd. 42, 1925. 15) 田中堅輔, 實驗整學雜誌. 第12卷, 昭和 3 年, 16) S. Zlatogoroff, P. Glusmann u. L. Kandyba, Z. f. Hyg u. Infektkrh. 1929 . 17) 額田晋，几てろいんむに乙療法，昭和5年，18）大谷淋亮，刺戟療法、昭和4年。19）

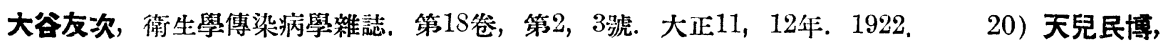

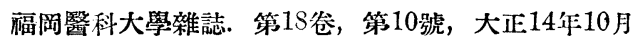

